Volume 39

Issue 4 Summer 1990: Symposium - Politics,

Religion, and the Relationship between Church

Article 5 and State

\title{
The Confrontation of Religious Faith and Civil Religion: Catholics Becoming Justices
}

Sanford Levinson

Follow this and additional works at: https://via.library.depaul.edu/law-review

\section{Recommended Citation}

Sanford Levinson, The Confrontation of Religious Faith and Civil Religion: Catholics Becoming Justices, 39 DePaul L. Rev. 1047 (1990)

Available at: https://via.library.depaul.edu/law-review/vol39/iss4/5

This Article is brought to you for free and open access by the College of Law at Digital Commons@DePaul. It has been accepted for inclusion in DePaul Law Review by an authorized editor of Digital Commons@DePaul. For more information, please contact digitalservices@depaul.edu. 


\title{
THE CONFRONTATION OF RELIGIOUS FAITH AND CIVIL RELIGION: CATHOLICS BECOMING JUSTICES*
}

\author{
Sanford Levinson**
}

\begin{abstract}
Roman Catholicism represents a beautiful anachronism in our age of crazed nationalism; virtually every devout Catholic preserves in his heart some remnants of his denomination's transnational loyalty and the duty of Catholics to defy immoral laws. ${ }^{1}$
\end{abstract}

\section{INTRODUCTION}

Consider some possible reactions to this recent comment by Istvan Deak, found, not at all coincidentally, in an article on the range of response to state-sponsored evil during the Holocaust. One might challenge its empirical accuracy on two separate grounds. First, one might question the assertion that Roman Catholicism in fact continues, assuming it ever did, to promote some kind of "transnational loyalty" that can stand firm against the "crazed" excesses of nationalism. Or, to the extent that one concedes the reality of this "transnational loyalty," one might argue that Catholicism is simply a subset of the much more general and important set of religious institutions. All of these institutions-or at least those we are most familiar with in the West-tend, by asserting the existence of a living sovereign God, to challenge the idolatrous claims of the nation-state. One might also be interested, of course, in the perceived social meanings, both within the Catholic community and outside, of membership in the Roman Catholic Church (the "Church").

- The initial version of this Article was presented at the Charles S. Casassa, S.J., Conference at Loyola Marymount College on The American Constitutional Republic: Triumphs and Dilemmas, in Los Angeles, California, on March 10, 1989. I have also presented it to a faculty colloquium at the University of Texas Law School, to the Ethics, Rationality, and Society Seminar at the University of Chicago and to the Faculty Workshop on Law and Jurisprudence at the Columbia Law School. I am grateful for the comments and criticisms made on those occasions. I am particularly grateful to the detailed comments of my University of Texas colleagues Douglas Laycock and Teresa Sullivan. I have also benefitted from responses to various drafts of this paper by George Fletcher, Robert George, Alan Hyde, Lewis LaRue, Richard S. Myers, Fred Schauer, Thomas Shaffer, Stephen Siegel, Allen Silver, Mark Tushnet, and Laura Underkuffler. Given the delicacy of the issues raised below, it is more necessary even than usual to emphasize that only I can be blamed for any infelicity of expression or errors of analysis in what follows.

Finally, it is a source of special pleasure to publish this Article in the DePaul Law Review, for I was shown extraordinary hospitality by the DePaul faculty and students when I spent two days there in April 1988 as a visitor. I wish especially to note the many kindnesses shown me both then and afterward by Professor Stephen Siegel.

* Charles Tilford McCormick Professor of Law, University of Texas Law School.

1. Deak, The Incomprehensible Holocaust, N.Y. Review of Books, Sep. 28, 1989, at 66. 
That is, independent of empirical demonstrations-however we might imagine such things-of a willingness to oppose state demands, do committed Catholics describe themselves in such a fashion?

Putting these empirical questions to one side, one could also respond to the value claims quite obviously contained within Deak's description of the Church. Here again there are two possibilities: one is to be thrilled by the recourse to moral claims transcending the often amoral and sometimes immoral claims of the nation-state. But another, drawn from a devotion to the claims of the nation-state as a Hobbesian barrier against the ravages of anarchy, is to be dismayed by the possibility of such recourse. Indeed, a person with this latter view may well feel impelled to limit, if not eliminate, the existence of this threat to state sovereignty.

Indeed, Deak's formulation raises in its own way the classic eighteenthcentury problem of imperium in imperio, the so-called "dual sovereignty" dilemma that was resolved, for American constitutional theory, by the fiction of the sole sovereignty of "we the people" who happened to subdivide the structures of government into various competing components. With popular sovereignty presumably comes an obligation to obey the will of the sovereign as manifested in legal commands, or so it is often suggested. But what if "the people" turn out, even in theory, ${ }^{2}$ not to be indisputably sovereign after all, if their decisions are in fact subject to challenge, or even negation, by a competing sovereign? At the very least, it should be obvious that Deak's beautifully compressed sentence carries within it implications for those of us who purport to analyze social life, whether as empirically-oriented social scientists, latter-day Geertzian interpreters of social meaning, or traditional political theorists concerned about such subjects as political sovereignty or theories of obligation. The purpose of this Article is to explore some of these implications.

I want in particular to examine some of the implications of the subsuming of religious identities within the more secular-or at least non-sectarianculture of American constitutionalism. My explorations will focus, by and large, on exchanges occurring during confirmation hearings held in regard to Catholic nominees for the United States Supreme Court. (A subject of this Article is to ask what we mean by referring to someone as a "Catholic nominee').

I should emphasize in advance that this Article is in no way an attempt to predict judicial behavior or even the judicial language that will be used by a member of the Supreme Court offering justifications for decisions. Instead, I am trying to do something else, to examine the American civil religion in operation by focusing on a specific, highly stylized, ceremony of that religion-the investiture of new justices as high priests of the sacred constitutional text. This discourse, I believe, encompasses a fear that the "private" realm

2. It is, of course, clear that popular sovereignty as an empirical matter is either false or empirically untestable. For a valuable study of the subject, see E.S. Morgan, INVENTING the People: The Rise of Popular Sovereignty in England and America (1988). 
of religion-and, more particularly, given our particular national past as a highly anti-Catholic, Protestant social order, of Catholicism-will illegitimately invade the public space of judicial decisionmaking. As a result, this concern about the "private" invasion of the "public" ends up by subtly forcing upon those who would become public officials a revision of one's "private" identity as a religious being.

This influence on private identity is evident in the context of judicial appointments. I believe that Justices identified with Catholicism have been forced to proclaim the practical meaninglessness of that identification. To refer to one of my specific examples, William Brennan ${ }^{3}$ in effect claimed that his Catholicism is formally irrelevant as he reassured the Senate, and therefore the rest of the nation, that it would play no role whatsoever in his understanding of the judicial role. This suggests, among other things, that identifying someone as a Catholic Justice provides only the same illuminationeffectively none at all-as might be provided by identifying him as a blueeyed Justice. How plausible is this suggestion? If true, it surely disconfirms any of Deak's assertions about the social meaning of Catholicism. If, though, we do believe that religion matters (or, more modestly, might matter), then we must confront a very troublesome question: should we countenance legislative probes into the meaning of a nominee's Catholicism to her/himself and, ultimately, to the nation that s/he helps to lead? Whatever else may be true about this Article, I hope that it will demonstrate that the question is a serious one demanding more serious treatment than it has tended to receive.

My goal in this Article is not so much making an argument as attempting to provoke a conversation about the cultural structures of American life and some of the ramifications of the peculiarly American solution to the role of religion in public life. This is especially the case in regard to the topic under discussion, for I freely confess my own uncertainty about the views under consideration. This particular Article should be conceived, therefore, as a "work in progress" as I try to work out the various conundrums that my work so far has enabled me to discern.

I will proceed first by laying out some basically empirical observations about patterns of assimilation in the United States. The heart of the Article, though, will focus on public discourse linked with the appointments to the Supreme Court of members of the Roman Catholic Church, particularly Justices Brennan, Scalia, and, to a lesser extent, Kennedy.

\section{Civil Religion ANd Judicial OAths}

The relationship between religious faith and adherence to the Constitution has been the topic of much discussion. Much of my scholarly work has been an attempt to conceptualize the American constitutional order as a "civil religion." ${ }_{4}$ One of the formal tenets of that religion, I argue, is that it

3. Like, for that matter, Antonin Scalia after him-the last thing I want to do in this Article is to suggest that I have any interest in counterposing "liberal" to "conservative" Justices.

4. See S. Levinson, Constitutional Faith (1988). 
professes to know neither Christian nor Jew but only "Americans" constituted in significant measure by their common adherence to the Constitution. This notion is most passionately captured in Justice Frankfurter's anguished statement, coming immediately after the identification of himself as a member of "the most vilified and persecuted minority in history," that, nonetheless, "as judges we are neither Jew nor Gentile, neither Catholic nor agnostic. We owe equal attachment to the Constitution and are equally bound by our judicial obligations."'s

This obligation, of course, is immediately derived from the judicial oath, which had much earlier served as a predicate for judicial review itself in Marbury v. Madison. ${ }^{6}$ To a degree that we can no longer appreciate, eighteenth-century Americans took oaths with extreme seriousness. ${ }^{7}$ We should thus pay special attention to article VI of the Constitution, where a prohibition of any religious tests as a condition for public office is coupled with a requirement that all public officials of state and nation take an oath of fidelity to the Constitution. ${ }^{8}$

As a Jew, I have a special reason to be grateful for the prohibition of religious test oaths, though in fact the list of those owing gratitude goes far beyond the relatively few members of the Jewish community or those who do not adhere to any religion at all. It was certainly not inevitable that the United States would choose to march along a path of religious toleration in deciding who was eligible to serve as a public official, Neither Jews nor Catholics, among many others, had any special reason 200 years ago to believe that they would be truly welcomed into the political fellowship of the new nation that had wrested its independence from Great Britain. After all, such complete toleration was not to be found in such luminaries as Locke or John Milton. And, as Thomas Curry has noted in The First Freedoms, his extremely valuable study of church and state before the passage of the first amendment in 1791, initial American notions of the relationship between pulpit and government were carried on "within a framework wherein Protestant Christianity and American culture intertwined."

5. Board of Education v. Barnette, 319 U.S. 624, 646-47 (1943) (Frankfurter, J., dissenting).

6. 5 U.S. (1 Cranch) 137, 180 (1803).

7. There is something richly symbolic about the fact that literally the first law passed by the new government of the United States established a framework of oaths of office. See An Act to regulate the Time and Manner of administering certain Oaths, ch. 1, 1 Stat. 23 (1845).

8. The pertinent part of article VI reads,

The Senators and Representatives before mentioned, and the Members of the several State Legislatures, and all executive and judicial Officers, both of the United States and of the several States, shall be bound by Oath or Affirmation, to support this Constitution; but no religious Test shall ever be required as a Qualification to any Office or public Trust under the United States.

U.S. Const. art VI, cl. 3. See Bradley, No Religious Test Clause and the Constitution of Religious Liberty: A Machine That Has Gone of Itself, 37 CaSE W. REs. 674 (1987) (general discussion of article VI).

9. T. Curry, The First Freedoms: Church and State in america to the Passage of 
As Professor Bradley has observed, the no test oath clause "is the only occasion on which the Constitution's makers actually addressed" the relationship between law and religion. ${ }^{10}$ Not the least remarkable aspect of the clause is that it was placed in the Constitution at a time when at least twelve of the states, and perhaps Virginia as well, employed religious tests as a prerequisite for holding public office. ${ }^{11}$

It is not clear why the no test oath clause made its way into the Constitution. I suspect that the most plausible explanation is simply the fear of each particular sect that it might become the victim of any test actually chosen, so that it was safer to prohibit all oaths. Professor Bradley has demonstrated beyond doubt, though, the rank implausibility of any notion that they were motivated by an affirmative desire on the part of most Americans to welcome Catholics, Jews, or, perhaps most unthinkable of all, atheists, into positions of leadership. ${ }^{12}$ Although developments since 1787 have scarcely been unmixed, it is clear that formal religious tests have indeed played no role, at least at the national level, and even informal ones have become ever weaker throughout our history. ${ }^{13}$

I believe that we can only applaud these developments and praise the drafters of article VI, whatever their motivations. One's appreciation for the formal elimination of sectarian affiliation as a precondition for public office increases as one looks around at certain other societies, whether dominantly Christian, as in Northern Ireland; Jewish, as in Israel; or Islamic, as in Lebanon. All of these countries are riven by continuing political and social cleavages predicated on sectarian differentiation even within these apparently

THE First Amendment 218 (1986) (emphasis added). Curry goes on to note that at the time of the Northwest Ordinance, in 1787, "a country wherein eleven of thirteen states restricted officeholding to Christians or Protestants hardly envisaged Catholicism or Judaism, not to mention Mohammmedism or any non-Christian group," as within the cultural consensus. Id. at 221. See also M. BoRDEN, JEWs, TURKS AND INFDELs (1984) (discussion of the development of religious liberty within a Christian nation). Finally, Professor Bradley, commenting that "the Founders' anti-Catholicism would be difficult to overestimate," notes that John Jay, our first Chief Justice (and co-author of The Federalist), "frankly estimated Catholicism and American citizenship to be fundamentally incompatible." See Bradley, supra note 8, at 699 .

10. Id. at 677 (emphasis in original). The first amendment, of course, was added after the drafting and ratification of the Constitution.

11. Id. at $679,681-87$.

12. Id. at $710-11$.

13. But see Crosson, Religion and Natural Law, 8 CCIA AnNual: Lmberty and Law: Crvil AND Religrous 75 (1989). "We have, despite our Constitution, a de facto religious test for office." Id. at 94. By this I presume that Professor Crosson is suggesting the unlikelihood of a professed atheist succeeding to high office, and possibly even the necessity of public officials' suggesting that they adhere to something called "the Judeo-Christian tradition." At the formal level, though, Torcaso v. Watkins, 367 U.S. 488 (1961) (invalidating a Maryland test oath) certainly remains an accurate statement of positive constitutional law, with its evocation of "the historically and constitutionally discredited policy of probing religious beliefs by test oaths or limiting public offices to persons who have, or perhaps more properly profess to have, a belief in some particular kind of religious concept." Id. at 494. 
overarching religious categories. ${ }^{14}$ Still, I think we have all become aware that political life often presents paradoxes, so that even the most beneficial policies almost inevitably turn out to have hidden costs. One cost inherent in our government may be the diminution of individual religious identity in the lives of public servants.

\section{Sameness, Difference, Religion, And Politics}

\section{A. Sameness and Difference}

One way of conceptualizing the problem is to place it within the context of the much-discussed issue of "sameness and difference" in social life. That is, whether one is referring to race, gender, or practically anything else, many of the arguments boil down to two contradictory assertions. At least some of the time proponents of members of group A (blacks, women, Jews, for example) will argue that they are really the "same" as some group B (whites, men, Christians) that is socially favored. The equality principle that like should be treated alike thus reveals the unfairness of treating "similar" groups differently. However, one sometimes finds the very same proponents arguing that there are really significant differences between the A's and the B's. Here, the problem is alleged to be the violation of what might be termed the "inequality" principle. This principle advances the idea that it is legitimate, and sometimes necessary, to treat different groups differently, so that the unfairness is the application of a single criterion to the A's and B's that collapses the differences between them. Thus, for example, an Orthodox Jew serving in the Air Force claimed, unsuccessfully, that the Constitution protected his right to wear a yarmulke. This was in contradiction to a rule promoting sameness by prohibiting the wearing of any hat besides the one that is part of the Air Force uniform (and that, of course, can be worn only when appropriate). ${ }^{15}$

The question before us in this instance is the meaning of religious identity. To what extent does the identification of oneself as "religious" entail as well a suggestion of significant differences existing between the religious and the irreligious? Does such an identification also imply a distinction between the specific denomination with which one identifies, and all others, whether of different religious commitment or irreligious? And are there occasions when these differences can-or must-be taken into account in the making of public policy? To what extent, on the other hand, are such ostensible differences irrelevant, to be dismissed as we emphasize instead the more important

14. This is clearest in Northern Ireland, where the conflict is between Catholic and Protestant. But if there were no Arabs, either Christian or Moslem, in Israel, there would still be bitter tensions among elements of the Jewish community, just as there are equally strong tensions within the Islamic community of Lebanon.

15. See Goldman v. Weinberger, 475 U.S. 503, 509-10 (1986) (no first amendment violation in Air Force regulation that prohibited a serviceman from wearing a yarmulke). 
"sameness" of each of us? Andrew Greeley has argued that "[m]odern sociology emerged in substantial part from a discussion of the differences between Catholics and Protestants." 16 Others have placed the emergence of sociology more in the "attempt[] to formulate and nurture secular and civil sources of morality to replace those of religion." 17 In any event, it is clear that a classical concern of sociology is the place of a religious dimension in the social order, whether religion be defined traditionally or in terms of "civil religious" replacements for more God-centered institutions. The implications for the general social order of religious identification, or the likelihood of achieving a robust civil religion, is, of course, of interest to far more than the sociological community.

One reason for the interest in "difference," alas, is the propensity Lucinda Finley has noted, discussing gender classification: "to be considered different can mean being stigmatized or penalized." 18 She links stigmatization to an "assimilationist idea" that links an entitlement to equal treatment with the recognition on the part of power holders of the essential "sameness" of those seeking such treatment with themselves. Thus, argues Finley, "the recognition of difference threatens our conception of equality, and the proclamation or identification of difference can serve as a justification for existing inequities." 19 One option, of course, is for members of the subordinated group to proclaim its essential similarity to the dominant group, but this may simply mean that the former must behave like the famous Marrano Jews of Spain, who hid their difference from the Christian majority that demanded sameness as the price of social inclusion. A further possibility, of course, is that the subordinated group actually does change in important ways and takes on the attributes of the favored majority.

\section{B. The Influence of Sameness on Religious Identity}

This discussion of sameness and difference is, of course, all very abstract. It is time to become more concrete. Before moving on to the issues raised by Catholic appointees, I want briefly to note how I have recently addressed some of these problems in regard to a study by Professor Robert Burt, Two Jewish Justices, about Justices Brandeis and Frankfurter. ${ }^{20}$ Though it is clear that all of us identify these two as "Jewish justices," I think it important that neither Brandeis nor Frankfurter exhibited any real interest in their adult lives in what might be termed traditional Judaism. I titled a review of Burt's

16. Greeley, Protestant and Catholic: Is the Analogical Imagination Extinct? 54 AM. Soc. REv. 485, 485 (1989).

17. Letter from Prof. Allen Silver, Department of Sociology, Columbia University to Sanford Levinson 2 (Dec. 10, 1989) (copy on file with the author).

18. Finley, Transcending Equality Theory: A Way Out of the Maternity and the Workplace Debate, 86 Colum. L. Rev. 1118, 1154 (1986).

19. Id.

20. R. Burt, Two Jewish Justices: Outcasts In the Promised Land (1987). 
book Who Is a Jew(ish Justice)?"1 In it I commented, "What is attractive about Brandeis and Frankfurter is precisely that they offer ways of being Jewish without accepting any specifically Jewish theological tenets or observing any mitzvot [commandments of Jewish law]." 22 One discovers the paradox, that their concrete beliefs "consisted of commitment to a mixture of Athenian and Enlightenment ideals, as opposed to the words of a living God who might command behavior contrary to some of those ideals." 23 The attractiveness I was writing about, I should make clear, is from the perspective of basically secular Jews like myself. "Judaism," in the case of Brandeis and Frankfurter, is far more a sociological than a religious category, at least where "religion" has anything to do with the affirmation of propositional notions about God and the world or the acceptance of specific behavioral duties imposed by the tenets of the religious community. Although both of them suffered from anti-Semitic opposition, I doubt that even the most overheated opponent of either man ever seriously suggested that either justice would be likely to subordinate the commands of the Constitution to those of the halacha, the Jewish law.

One point of my review was to question whether nonsecular Jews could feel quite the same sense of pleasure in Frankfurter's and Brandeis's careers as can secular Jews, given the fact that their success came in part because of their rejection of the particular disciplines imposed by traditional Judaism. A committed traditional Jew might be excused, though, for refusing to identify Brandeis and Frankfurter as the kinds of "Jewish Justices" that would truly resonate with their own sense of Jewish identity or provide inspirational role models. Instead, they would be symbols primarily of the necessity to give up any truly distinct-or different-religious identity in order to accommodate, and thus indicate the similarity to, the sensibilities of the wider community.

Writing that review, coupled with an invitation to participate in a symposium on the Constitution at Loyola Marymount College, a distinguished Catholic institution, led me to wonder if similar tensions might be revealed in the history of America's Catholic Justices. I doubt that a parallel title"Who is a Catholic Justice?" -would work. But the precise title is surely less important than the underlying problem, which is whether the pattern suggested by Brandeis and Frankfurter might be found as well in the stories of similarly eminent Catholic jurists.

As I noted at the outset, one social reality shared by Jews and Catholics is living within an historically Protestant culture that has been suspicious of both, though for obviously different reasons. Jews were thought untrustwor-

21. Levinson, Who Is a Jew(ish Justice)? (Book Review), 10 Cardozo L. REv, 2359 (1989), One of my purposes in choosing that title is obviously to play on the contemporary controversy taking place in both Israel and the United States concerning the criteria that must be met for a convert to Judaism to be regarded as "genuinely" Jewish for purposes of Israeli law. No issue more sharply divides the American and Israeli Jewish communities.

22. Id. at 2368.

23. Id. 
thy for our failure to accept the tenets of Christianity, whereas all but the most rabid anti-Catholics presumably recognized that Catholics were indeed Christian. Still, that common Christianity was itself riven apart in the storm of the Reformation. Even four hundred years later it has not completely subsided. This is in light of the historical fact that animus against Catholics was substantially predicated on the particular institutional role played by the Roman magisterium as what we might today describe as the "privileged" interpreter of the demands of the truly Christian life.

I am old enough to remember John Kennedy's trip to Houston, where he had to reassure Protestant ministers that he would, if elected, behave as a loyal American and not, as feared by his fundamentalist audience, in fact take orders from the Pope. "I believe in an America," said the man who would become our first Catholic President, "where the separation of church and state is absolute." 24 He rejected the propriety of any "religious body seek[ing] to impose its will directly or indirectly upon the general populace or the public acts of its officials." 25 Thus, he assured his audience,

Whatever issue may come before me as President-on birth control, divorce, censorship, gambling or any other subject-I will make my decision . . . in accordance with what my conscience tells me to be the national interest, and without regard to outside religious pressures or dictates. And no power or threat of punishment could cause me to decide otherwise. ${ }^{26}$

Put to one side that the Protestant ministers were almost certainly misinterpreting the authority assigned by in fact Catholic theology to the Pope and that Kennedy was merely correcting them. More to the point is that, in a variety of subtle ways, the views of outright anti-Catholics have become incorporated into the self-understanding at least of American Catholics forced, by the demands of the political process, to appeal to them for support. Perhaps this helps to explain the finding, in a cross-national survey analyzed by Andrew Greeley, that "differences between Protestants and Catholics," in a variety of attitudinal variables, "are more modest in the United States than in the other four countries" studied, Great Britain, Ireland, Canada,

24. Schlesinger, O'Connor, Vaughan, Cuomo, Al Smith, J.F.K., N.Y. Tìmes, Feb. 2, 1990, at A31, col. 1, 4. The article notes the declaration some thirty years before Kennedy's, by New York Governor Alfred E. Smith, the first Catholic to be nominated for the presidency, that "I recognize no power in the institutions of my Church to interfere with the operations of the Constitution of the United States or the enforcement of the law of the land. I believe in absolute freedom of conscience . . . in the absolute separation of church and state. . . " Id. at col. 2-3. The occasion for Professor Schlesinger's "op-ed" article was the declaration by Cardinal O'Connor of New York City that Bishop Austin Vaughan was correct in "warn[ing] any Catholic that his soul is at risk if he should die while deliberately pursuing any gravely evil course of action, and that such would certainly include advocating publicly, as the Bishop puts it, "the right of a woman to kill a child."' Verhovek, Cardinal Defends a Jailed Bishop Who Warned Cuomo on Abortion, N.Y. Times, Feb. 1, 1990, at A1, col. 1. See infra note 66 for further discussion of this controversy.

25. Schlesinger, supra note 24 , at col. 4.

26. Id. at col. 4-5. 
and Australia. ${ }^{27}$ In fact, though, even here statistically significant differences emerge from the data he has analyzed. ${ }^{28}$

The problem of survey data, of course, even aside from methodological considerations, is that at best it reveals only tendencies. There are obviously wide overlaps between any of the groups being analyzed; furthermore, it is always the case that there will be X's (perhaps in fact numbering in the millions) who will have more of the traits that "tend" to cluster in Y's than will be the case with many Y's (perhaps in fact also numbering in the millions), who will have the traits one associates with the X's. This is the basis for the reminder that one should never be confident about one's inferences about individuals on the basis of knowledge only of even the most impeccable macro-level data. Still, however well-advised we are not to draw conclusive presumptions from them, human life could scarcely proceed if we did not use such data for some kinds of filtering purposes, even if only to serve as the basis for further conversation designed to find out more about the particular individual we are interested in. There is a reason that we ask the questions we do at cocktail parties or mixers, where gross categories, such as occupation, regional background, education, and, indeed, religion are all used as predictors about likely attitudes or interests. Those predictions may well be disconfirmed by the further conversation. Still, we would probably stop asking the questions entirely if past experience had shown only random correlation between the answers and the deeper attributes about which we were "really" seeking information. To this extent we all rely on "stereotypes" even as we should feel wary about this.

\section{Catholic Justices: A Historical Perspective}

Let me now turn to some of the implications of these points for the topic under consideration-the assessment of Catholic nominees for the Supreme Court. How does the issue of sameness and difference work itself out in this context? Likewise, how might the presentation of their faith by American Catholics be influenced by the experience of living as a minority within a society that has often been characterized by at least a certain skepticism, if not virulent hostility, toward the legitimacy of the Roman Catholic Church?

\section{A. Anti-Catholicism and the Judiciary}

Even a cursory look at the historical record involving Catholic Justices certainly reveals the presence of overt anti-Catholicism. President Warren Harding, for example, was castigated by the members of the Women's Auxiliary of the Ohio State Good Government Association when he nominated

27. Greeley, supra note 16 at 493.

28. For example, "in all countries Catholics are more likely to emphasize 'fairness' and 'equality' while Protestants are more likely to emphasize 'freedom' and 'individualism' in the workplace. With the exception of Great Britain, Catholics are also more likely to advocate strengthening of authority and of the family." Id. 
Pierce Butler for membership on the Supreme Court. They described the Roman Catholic Church as "un-American" and did not understand how Harding could appoint one of its members to our highest court. ${ }^{29}$ Still, the major attack on Butler was because of his conservatism, and he was easily confirmed by the Senate. In addition, Butler was by no means the first Catholic to gain membership on the Supreme Court. That achievement was Roger Brooke Taney's, who succeeded John Marshall as our fifth Chief Justice in 1836. He had, to be sure, been rejected once before, but no one seriously argues that his Catholicism, rather than his devoted service to his patron Andrew Jackson, explains the episode..$^{30}$ Edward White, a Louisiana Catholic, filled Taney's office in 1910, after reaching the Court in 1894, and three other Catholic Justices served over the next forty years. Joseph McKenna, a notably obscure jurist, served from 1898 to 1925 . His last three years overlapped with the term of the aforementioned Pierce Butler, who fought the good fight against President Roosevelt's New Deal and died while on the Court in 1939. He was succeeded by another Catholic, Frank Murphy, who died prematurely in 1949. President Eisenhower named William Brennan to the bench in 1956, shortly before the Presidential election, in a move viewed as shoring up his support among Northeastern Catholics. ${ }^{31}$ Finally, Justice Brennan has been joined by his co-religionists Justices Scalia and Kennedy in the last three years.

One doesn't exactly know what to do with these figures: the approximately seven percent appointment rate for Catholic justices is significantly smaller

29. D. Danelski, A Supreme Court Justice is Apponsted 92 (1964).

30. See Perry, The Life and Death of the "Catholic Seat" on the United States Supreme Court, 6 J.L. \& Pol. 55, 60 (1989). Perry offers a very useful overview of the nominations of each of the eight "Catholic justices." Her thesis is summarized in the following paragraph:

[I]n none of the eight Catholic appointments (nine counting White's promotion to Chief Justice) was religion the overriding factor in the President's selection. Nevertheless ... Catholicism [evolved] from a coincidental factor or actual handicap to be overcome (Taney and White's first appointment), to what I label an "over-thetop" consideration (McKenna and White's promotion), to an explicit concern of advisers to the President (Butler), to its high point as one of the President's top two or three concerns (Murphy). The gap between Murphy's and Brennan's tenures on the Court, and the lessening emphasis on the latter's religion, weakened the tradition of the "Catholic seat." More recently, Scalia's Catholicism arguably was not an unwelcome characteristic for President Reagan and his advisers to consider, but it is apparent that his ideology, jurisprudence, age, and even ethnic ties were all more decisive actors in his selection. Finally, Kennedy's appointment has brought Catholic religious affiliation full circle to its previous status as a purely coincidental factor in nominations to the Supreme Court.

Id. at 91 .

31. This triggered a denunciation by Fred Rodell of the Yale Law School of Brennan as "a technical Democrat of such conservative stripe" as to be described best as "a charming Catholic Republican." See Rodell, The Joker of Judicial Experience, ThE Progressive, January, 1957, at 9. This was, to put it mildly, not one of Professor Rodell's best moments, either as a predictor or as an exemplar of religious tolerance. For a more scholarly discussion of the importance of Brennan's Catholicism as an explanation for his nomination, see Perry, supra note 30, at 83-85. 
than the population of Catholics in the United States, at least since the great migrations of the 1820's and 1830's. On the other hand, three out of nine, the current figure, is scarcely evidence of underrepresentation, assuming that one wants to use such language at all. ${ }^{32}$ For many decades, though, Roman Catholics have been able to look at the United States Supreme Court and see evidence of their legitimate membership within the wider ambit of the American polity.

As Judge Noonan has written, the praise visited upon Chief Justice White by Justice Holmes and the support given Butler by established, and largely Protestant, businessmen demonstrated to Protestants "that they did not need to fear Catholics in high position in the federal government," and to Catholics that they were indeed accepted. ${ }^{33}$ Anti-Catholic bigotry might blight the political landscape, as anti-Semitism certainly did in regard to the Brandeis and Frankfurter nominations, but the more important point is that the bigots were unsuccessful, and all of these nominees were accepted as fit members of the bench.

Judge Noonan, who is of course himself both a committed Catholic and a distinguished federal judge, cautions, though, that this acceptance came at a certain price: "silence" as to what might truly be "distinctive" about being a member of the Roman Catholic religious community. But, says Noonan, no one was inclined to notice this "when the difference in beliefs between Catholics and other Americans appeared in practice to be small." ${ }^{34}$ For Jews and Catholics alike, then, it seems plausible to argue that there is a price attached to entry into leadership positions within the polity. This price has been the modulation, if not outright suppression, of much awareness of anything within their respective religious traditions that might be significantly different from-let alone pose a challenge to-the wider American (and Protestant?) culture. Is it significant, for example, that all three of the current Catholic members of the Supreme Court, like Justices Brandeis and Frankfurter, went to the decidedly secular Harvard Law School, which could validate their identity as assimilated Americans? Indeed, only Justice Scalia went to a Catholic school for his undergraduate education-Georgetown; Justices Brennan and Kennedy went to the University of Pennsylvania and Stanford, respectively. The "differences" some might have seen as following from disparate religious sensibilities were minimized, in favor of the "sameness" of socialization within the subsuming American political order.

\section{B. The Influence of Secularism}

To a significant extent, of course, religious traditions themselves have lost their hold on many members of the wider culture-thus the emergence of

32. There has not, for example, been a Jewish justice now for twenty years, since the forced resignation of Abe Fortas, though the Reagan Administration can perhaps be "credited" with the desire to supply such a justice by virtue of the ill-fated nomination of Douglas Ginsburg.

33. Noonan, The Catholic Justices of the United States Supreme Court, 67 CATH. Hist. REV. 369, 378 (1981).

34. Id. at 379. 
the "secular Jew" as a distinct social, rather than religious, category. I do not know whether the category of "cultural Catholic," used sometimes to refer to those still significantly marked by a background in the Church even if they have formally left it, is truly similar. I am unaware that the notion of "secular Protestant" has any contemporary meaning at all in our society. In any event, it is clear that many people born and raised in these respective religious communities have left them behind as they have moved self-consciously into a more secular understanding of the world.

It is important to note, though, that "secularism" has a far different meaning within American culture than it bears elsewhere, for here there has been far less of the outright anti-religious animus that is such an important part of European history. No serious American political party, for example, has ever defined itself as proudly secular and overtly hostile to the expression of any religious sensibility in public life. ${ }^{35} \mathrm{I}$ am not, however, primarily interested in such persons who present themselves self-consciously as "secular," whether in its European or more gentle American definitions. Instead, I am interested in the self-presentation of persons who continue to affirm the meaningfulness to them of membership in religious communities even as they also take on responsibilities of public office at the highest levels of government.

This necessarily raises an important question: has there been a significant redefinition in our culture of what it means to adhere to religion? I am inclined to answer yes, with the most important development being what I would call the "privatization of religious identity." Protestant theology has in fact significantly affected almost all of us within the United States, whatever our formal identification. It is to certain strands of Protestant thought, especially as interpreted by more secular liberal political theorists, that we owe our almost instinctive identification of religion as essentially "private," that is, basically unrelated to our common lives as citizens in a collective enterprise. ${ }^{36}$ Although there is bitter dispute over what the nature of those common lives or collective enterprise might be, there is, partly as a result of article VI, wide agreement that its definition must be nonreligious.

It should be obvious that this privatizing of religion and the concomitant separation of the public from the private is scarcely inevitable or uncontroversial. Traditional Judaism was historically totalistic in its scope, as the commands of the Jewish law, the halacha, reached from the bedroom to the public square. Indeed, a source of tension within contemporary Israel is precisely what it means to take seriously the task of being a "Jewish state"; there are many (too many, from my perspective) who argue that it requires that the state enforce halachic norms, including, for example, observance of

35. I owe recognition of this point to Allen Silver.

36. See Bradley, Dogmatomachy: $A$ "Privatization" Theory of the Religion Clause Cases, 30 ST. Lours U.L.J. 275 (1986) (discussing the Supreme Court's treatment of the religion clauses, which has eliminated the influence of religious factions and shaped religion into a private matter). 
the Sabbath even against those Jews who are not observant. Similar controversies are raging within Islamic societies.

The Roman Catholic Church certainly has not, at least historically, been identified with a strong separation between a religious, private, realm and a secular, public one. ${ }^{37}$ Protestants per se have surely not proved unwilling to use state power in behalf of religious ends. However, there is in Protestantism much more of an analytical separation between the realms of God and Caesar, particularly in the pietistic traditions associated with the Lutheran Reformation and subsequent developments. ${ }^{38}$ Thus on ${ }^{39}$ is inclined to identify the Roman Catholic Church, far more than any Protestant church, with calls for the organization of the public realm in many respects on the basis of the decidedly non-relative, transcultural moral norms of natural law, as distinguished from norms that are the product of more specific religious revelation. Indeed, is not this the heritage that Deak is making reference to in the comment quoted at the outset of these remarks? No doubt, as I have been reminded by a friend, himself a secular Jew teaching at Georgetown University, there have been major changes in Catholic doctrine on this point following Vatican II, and the Church may today be far less "militant" in its

37. As is true almost of any statement about the institutional Catholic Church, the reality is more complicated than the text suggests. Pope Gelasius I, in addressing the Roman Emperor Anastasius in 494 C.E., articulated a distinction between "sacred authority" (auctoritas) of the priesthood and the "royal power" (potestas) of the emperor and indicated that "the bishops themselves, recognizing that the imperial office was conferred on you by divine disposition, obey your laws so far as the sphere of public order is concerned." See Gelasius I, Letter to Emperor Anastasius, quoted in B. TIERneY, The Crisis of Church and State, 1050-1300, at 13-14 (1964). This quote was also mentioned by William Luckey at the annual meeting of the American Political Science Association in 1989. See W. Luckey, The Role of Religion in Modern Democracy in the Political Thought of John Courtney Murray, S.J. 3 (Aug.- Sep. 1989) (unpublished manuscript). Professor Luckey noted that this Gelasian understanding of separate spheres was supplanted in the Middle Ages by "political Augustinism" culminating in the Bull Unam Sancta of Pope Boniface VIII in 1302, which stated "that the temporal sword is in the power of Peter" and his papal successors. Id. at 5 . In reaction, some medieval writers, including Dante and Machievelli, wrote in behalf of secular rule "completely free from the spiritual auctoritas." Id. at 6. Luckey went on to analyze the important thought of John Courtney Murray, who sought a middle way between these two positions and whose thought was enormously influential in the decisions made by Vatican II in the 1960s. Id. at 6-23.

38. I have been reminded by Laura Underkuffler that in fact "[m]any Protestant groups ... see no separation between the religious and secular parts of their lives." In addition to certain "fundamentalist" sects, she includes as opponents of "compartmentalization of their lives" such groups as the Society of Friends (Quakers) and the Amish, Mennonites, and Schwenkfelders. Although she agrees that "the separation of the individual and collective" is certainly "a strong strain in Protestantism," it is just as certainly "not universal." Letter from Laura Underkuffler to Sanford Levinson (Nov. 22, 1989) (copy on file with author). See also Underkuffler, "Discrimination" on the Basis of Religion: An Examination of Attempted Value Neutrality in Employment, 30 WM. \& MARY L. REv. 581 (1989) (discussing the effects of employers' religious beliefs in the work place and the extent of legal intervention to prevent discrimination on the basis of religious beliefs).

39. The better word here may well be "I," standing perhaps for the non-Catholic community in general. 
proclaimed reach than was earlier the case..$^{40}$ One way of framing my remarks, though, is in asking how important it is that we (non-Catholics interested in American politics) become more knowledgeable about changes within the Catholic community. The answer depends, of course, on the potential relevance of the information to our political decisions, which brings us back full circle.

\section{Interrogating Catholic Nominees}

Professor Kent Greenawalt, who describes himself as religious, tells his readers that " $[\mathrm{m}] \mathrm{y}$ convictions tell me that no aspect of life should be wholly untouched by the transcendent reality in which I believe, yet a basic premise of common legal argument is that any reference to such a perspective is out of bounds." ${ }^{41} \mathrm{He}$ has devoted a recent book to considering the tensions implicit in these two assumptions. I will be borrowing from his analysis even as I try to develop its ramifications in a context that he leaves basically undiscussed, the confirmation process of persons nominated to serve on the United States Supreme Court. ${ }^{42}$

\section{A. The Judicial Confirmation Process}

Many functions are served by the judicial confirmation process. For those of us interested in political culture, the process serves mainly ${ }^{43}$ to demonstrate the creedal demands that nominees are expected to affirm. This affirmation provides symbolic reassurance that the nominees can be entrusted with the power of high office, which in the case of the Supreme Court of course

40. But see Vatican Council II, Declaration on Religious Freedom, no. 2, which notes that religious people should be free "to show the special value of their doctrine in what concerns the organization of society and the inspiration of the whole of human activity." Id. quoted in Hollenbach, The Common Good Revisited, 50 Theological Stud. 70, 90 (1989).

41. K. Greenawalt, Religious Convictions and Political Choice 5 (1988) thereinafter K. Greenawalt, Religious Convictions]. Among the most thoughtful reviews of the book are: Audi, Religion and the Ethics of Political Participation (Book Review), 100 Ethics 386 (1990); Richards, Book Review, 23 Ga. L. Rev. 1189 (1989) (also reviewing K. Greenawalt, Confucts of Law \& Moralrty (1987)); Tushnet, Book Review, 89 Colum. L. Rev. 1131 (1989). Professor Greenawalt elaborates his views and assesses the arguments of his critics in Greenawalt, Religious Convictions and Political Choice: Some Further Thoughts, 39 DE PAUL L. REv. 1019 (1990) [hereinafter Greenawalt, Some Further Thoughts].

42. But see K. Greenawalt, Religious Convictions, supra note 41, at 239-41, where Greenawalt offers a brief discussion of the propriety of judges making recourse to their religious convictions.

43. It can obviously be argued that confirmation hearings serve "mainly" to confirm or deny confirmation to nominees, as witnessed most recently by the Bork hearings. It is certainly true that confirmation hearings carry with them a "bottom line" of a yea or nea vote on capacity to serve on the Supreme Court, and to this extent the statement in the text may be overstated. Yet it is clear that most hearings do not carry with them a serious possibility of rejecting the nominee, and that they therefore take on the more purely "ritualistic" aspect noted in the text. (And, of course, even the Bork episode was highly ritualistic, whatever else it was as well.) 
includes lifetime tenure. The appearance of nominees themselves before the Senate Judiciary Committee is a comparatively recent development in our public ritual life. Not until the nomination of Harlan Fiske Stone to become an Associate Justice of the United States Supreme Court did a judicial nominee testify personally in front of the Senate Judiciary Committee. ${ }^{44}$ Before that the nominee remained well in the background, even as friends and opponents might appear before the Senate urging confirmation or rejection. It was with Felix Frankfurter's nomination in 1939 that our norms in this regard appear to have more significantly changed, and it has now become expected that nominees will indeed appear before the Senate (and, via CSPAN and the networks, before the American people) to answer a wide range of questions purportedly relevant to their fitness to serve. One of the key concerns is that nominees affirm that aspect of the American creed that requires them to subordinate any merely "personal" aspects of their selves to the demands placed on them by their public role.

\section{B. Recent Catholic Nominees}

Let us turn now to the Senate hearings considering the nominations of William Brennan, Antonin Scalia, and Anthony Kennedy to the Supreme Court. I begin with a specific exchange that occurred on February 27, 1957, during the hearings on the nomination of William J. Brennan to join the Court. Senator Joseph O'Mahoney of Wyoming asked special permission to direct a question at the nominee. ${ }^{45} \mathrm{O}^{\prime}$ Mahoney was himself a Catholic, as he emphasized when taking personal responsibility for asking Justice Brennan a question propounded by the members of the National Liberal League, an organization purportedly devoted to the separation of church and state. I say "purportedly" because the League indicated its opposition to the appointment on the ground that the United States, as "a predominantly Protestant country," should not have Catholics on its highest court. In any event, the League requested that Justice Brennan be asked the following question:

You are bound by your religion to follow the pronouncements of the Pope on all matters of faith and morals. There may be some controversies which involve matters of faith and morals and also matters of law and justice. But in matters of law and justice, you are bound by your oath to follow not papal decrees and doctrines, but the laws and precedents of this Nation. If you should be faced with such a mixed issue, would you be able to follow the requirements of your oath or would you be bound by your religious obligations? ${ }^{70}$

44. E. Bronner, Battle for Justice: How the Bork Nomination Shook America 220 (1989). On confirmation hearings in general, see the excellent article by Grover Rees III, Questions for Supreme Court Nominees at Confirmation Hearings: Excluding the Constitution, $17 \mathrm{GA}$. L. REv. 913 (1983); see also L.A. Powe, The Senate and the Court: Questioning a Nominee (Book Review), 54 Texas L. Rev. 891 (1976).

45. Nomination of William Joseph Brennan: Hearings Before the Committee on the Judiciary, United States Senate, 85th Cong., 1st Sess. 32-34 (1957).

46. Id. at 32. 
Justice Brennan then answered as follows:

Senator, I think the oath that I took is the same one that you and all of the Congress, every member of the executive department up and down all levels of government take to support the Constitution and laws of the United States. I took that oath just as unreservedly as I know you did, and every member and everyone else of our faith in whatever of fice elected or appointive he may hold. And I say not that I recognize that there is any obligation superior to that, rather that there isn't any obligation of our faith superior to that. And my answer to the question is categorically that in everything I have ever done, in every office I have held in my life or that I shall ever do in the future, what shall control me is the oath that I took to support the Constitution and laws of the United States and so act upon the cases that come before me for decision that it is that oath and that alone which governs. ${ }^{47}$

Justice Brennan in effect returned to this theme during an interview with a former law clerk on the 30th anniversary of his appointment to the Court. $\mathrm{He}$ was asked if he "ever had difficulty dealing with [his] own religious beliefs in terms of cases," and the Justice responded that he had, in 1956, "settled in my mind that I had an obligation under the Constitution which could not be influenced by any of my religious principles." Although he would "as a private citizen" do "what a Roman Catholic does ... to the extent that that conflicts with what I think the Constitution means or requires, then my religious beliefs have to give way." 49

A considerably tamer, though I think possibly even more interesting, version of the O'Mahoney-Brennan dialogue occurred during the August 1986 Senate confirmation hearings on the nomination of then Circuit Court Judge Antonin Scalia to be an Associate Justice of the United States Supreme Court. ${ }^{50}$ Interestingly enough, at no time during the hearing does explicit notice appear to have been taken of Justice Scalia's Catholicism. Instead, everyone emphasized the splendid fact that he would be the first Italian-American member of the Court.

Republican Senator Charles Mathias noted that Scalia had "expressed doubts about [Roe v. Wade, the Supreme Court's 1973 abortion decision,] both on moral as well as jurisprudential grounds." ${ }^{\prime}$ For reasons I shall suggest presently, I think that Catholic nominees might especially be the recipients of questions directed at their "moral" views, so that such inquiries are in some way only slightly concealed ways of inquiring into their religious beliefs. But there is also an obvious special interest in the views of Catholic nominees regarding the substantive issue of abortion, given the leading role

47. Id. at 34 .

48. S. Levinson, supra note 4, at 56 (quoting Leeds, A Life on the Court, N.Y. Times, Oct. 5, 1986 (Magazine), at 79).

49. Id.

50. Nomination of Judge Antonin Scalia: Hearings Before the Committee on the Judiciary, United States Senate, 99th Cong., 2d Sess. 43-47 (1986) [hereinafter Scalia Hearings].

51. Id. at 43 . 
taken by the Catholic Church in attacking the moral legitimacy of abortion and of its legal tolerance..$^{52}$ It is within this context, then, that one must understand both the question directed at Judge Scalia and his answer.

Judge Scalia replied that although he may well have criticized Roe, "I do not recall passing moral judgment on the issue." He immediately went on to reassure Senator Mathias that "I agree ... that one of the primary qualifications for a judge is to set aside personal views."

Senator Mathias probed further: "What does a judge do about a very deeply held personal position, a personal moral conviction, which may be pertinent to a matter before the Court?" The answer, according to Scalia, is to recognize the moral obligation that comes with living "in a democratic society and to be bound by the determinations of that democratic society. If he feels that he cannot be, then he should not be sitting as a judge." $\$ 4$ Even if he as a Justice were faced with laws "that I might even think in the largest sense are immoral in the results they produce ... [i]n no way would I let that influence my determination of how they apply."ss Should he feel unable to separate his personal moral feelings from his duties as a servant of the law, he would recuse himself from the case. ${ }^{36}$

Finally, at his confirmation hearing, Anthony Kennedy was asked by Senator Biden about a column written by Cal Thomas, a former official of Jerry Falwell's "Moral Majority," in which Thomas purported to describe a conversation between Kennedy and Senate Jesse Helms of North Carolina. ${ }^{57}$

52. Of course, some Catholic political leaders, including Mario Cuomo and Geraldine Ferraro, have been specifically criticized by officials of the Church for their failure to support the Church's stands. See infra note 66.

53. Scalia Hearings, supra note 50 , at 43.

54. Id.

55. Id.

56. Id. John Leubsdorf, while discussing an earlier presentation of this Article at Columbia on December 11, 1989, brought to my attention the structural linkage between the problem addressed in the Article-judicial confirmation-and the issue of judicial recusal (or involuntary disqualification) based on the purported "partiality" of a judge because of his or her having certain attributes, including that of membership in given religious bodies. Thus he noted that lawyers on occasion have filed recusal motions in regard to Catholic judges on the grounds that they could not dispassionately assess certain issues presented by the case before them, such as the meaning of the establishment clause as it relates to state aid to parochial schools. Such motions, he said, have rarely, if ever, been successful. Though recusals are beyond the scope of this particular Article, they are obviously relevant to the overall topic, both in terms of the perceived difference (or sameness) of Catholic and non-Catholic judges and the response of the operational judicial system to these perceptions.

In addition to Leubsdorf, I am indebted as well to Arthur J. Jacobson of Cardozo Law School who has shared with me materials on judicial disqualification that will form part of a casebook, Justice and the Legal System: A Coursebook, that he is preparing with Anthony D'Amato. See also Judge Jerome Frank's opinion in In re J.P. Linahan, 138 F.2d 650, 652-53 (2d Cir. 1943) ("Much harm is done by the myth that, merely by putting on a black robe and taking the oath of office as a judge, a man ceases to be human and strips himself of all predilections, becomes a passionless thinking machine.")

57. The Questions Begin: "Who is Anthony Kennedy," N.Y. Times, Dec. 15, 1987, B16, 
Helms was quoted as saying, "I think you know where I stand on abortion." According to Thomas, "Judge Kennedy smiled and answered, 'Indeed I do and I admire it. I am a practicing Catholic." "s8 In response to Senator Biden's inquiry about the accuracy of the column, Judge Kennedy noted that "I admire anyone with strong moral beliefs. Now it would be highly improper for a judge to allow his or her own personal or religious views to enter into a decision respecting a constitutional matter." 59

\section{Personal Identities and Societal Implications}

An analysis of these nomination hearings, thirty years apart in time, may help to explain the way the American political culture tries to come to terms with the problem of personal identities. Here, of course, I am interested in one particular-and volatile-mixture: on the one hand, there is one's selfunderstanding as what Michael Sandel, one of our leading "communitarian" political theorists, might call an "encumbered" member of a religious community. Such a community might make demands on its members ranging from what appear to be relatively non-morally freighted rituals (for example, fasting on particular days) to adherence to what is generally thought the "essence" of morality (for example, non-participation in murder, whether capital punishment, for some, or abortion, for others). Professor Greenawalt describes, apparently with approval, the view that "it is scarcely possible for anyone who takes religion seriously to acquiesce in its being treated as a private matter. Unless there are good reasons for religious believers to discount the evident relevance of religious convictions for political choice, these convictions will affect some political decision they make." 60 On the other hand, there is one's self-understanding as a member of a pluralistic civil community, which calls for the suspension, or at least bracketing, of one's religious identity when entering the public arena. This bracketing may seem especially important if one chooses to accept a public office requiring that one act as an agent of others rather than as a first-order decisionmaker, as is the case presumably with the standard view of the judge. ${ }^{61}$

\section{Identification as a Public Official}

As I have suggested in my book Constitutional Faith, many readers probably take the subordination of religion, or "personal morality," to the Constitution as a sine qua non of what it means to be a public official. The

col. 4 (transcript of exchanges between members of Senate Judiciary Committee and Judge Anthony Kennedy).

58. Id.

59. Id. at col. 4-5.

60. K. Greenawalt, Reuigious Convictions, supra note 41 , at 35 .

61. See Schauer, May Officials Think Religiously? 27 WM. \& MARY L. REv. 1075 (1986) (discussing Greenawalt's position that public officials may base decisions on religious beliefs and suggesting, rather, that they may be precluded from doing so). 
"many" in this case would almost certainly include all who define themselves as secularist, for they by definition find intellectually implausible religionbased claims about the world. But others might feel distinctly less comfortable at the privileging of the demands of the secular state over one's religious duties. The "others" in this instance might include many who reject, at one level or another, a secular stance toward the world. Consider, for example, the remark of Professor Paul Simmons, a Southern Baptist: "For Christians and Jews, loyalty to God must transcend any earthly loyalties."62 Stanley Hauerwas, a Protestant theologian who has taught at Notre Dame has criticized the diminution within contemporary religious culture of a willingness on the part of believers to present "the Gospel as truth." He is particularly fearful that this has led as well to a significant weakening of "a Church that has a people capable of saying "no to the state"" or, indeed, "capable of challenging the state." ${ }^{63}$ From this perspective, what the secularist positively describes as adherence to one's constitutional duty can be given the much more negative description of idolatry. ${ }^{64}$

Whatever the obvious differences we might perceive between the politically liberal Justice Brennan and the conservative Justices Scalia and-Kennedy, their self-descriptions as judges within the civil realm seem remarkably similar. The ultimate question is whether we are genuinely reassured by these descriptions. It should be obvious, incidentally, that a linked task is to discover whether in fact there is a real "we" that shares a common perception of these justices' comments. It has become a truism of cultural criticism that the rhetorical use of the word "we" often is designed to suppress any

62. Quoted in S. LeVInson, supra note 4, at 57.

63. Id. at 118 (quoting S. Hauerwas, Freedom of Religion: A Subtle Temptation 2, 19 (unpublished manuscript)).

64. Indeed, Prof. Thomas Shaffer, the former Dean and now law professor at Notre Dame Law School, has told me that he opposed honoring Justice Brennan because he "understand[s] Brennan to be an idolater, plain and simple, and I (and many Catholics) are as solemn about idolatry as the Rabbis were." In a later letter, Prof. Shaffer has added that he finds Kennedy's answer "evasive," and he states that I "underestimate" an important aspect of Scalia's answer: "He said if the law required a result at odds with conscience, he would resign from the bench." What Shaffer emphasizes is that for him "the issue is idolatry." Insight into what might be meant by idolatry in this context is provided by Professor Yovel in his recent study of Spinoza: "If this world has no transcendent dimension, then some particular entity within the world can possibly gain metaphysical significance, and even be sanctified by some person as the foundation of his or life. This is not merely 'paganism' but outright idolatry." See Y. Yovel, 1 SpINozA and Other Heretics: The Marrano of Reason 123 (1989).

One might note in this overall context the controversy that developed in 1989 when Spalding University, a small Catholic university in Louisville, Kentucky, announced the award of an honorary degree to Justice Brennan. The Archbishop of the Louisville diocese. Thomas Kelly, announced that he would refuse to attend Spalding's commencement, and a local priest, claiming the support of Kelly, attempted to organize further protest. Although the University remained firm in its intention to honor Justice Brennan for his thirty years of service as a member of the Supreme Court, he ultimately chose not to attend the ceremonies. The University, however, awarded the degree to Brennan in absentia. Mauro, Brennan Gets an Education in 'Intolerance,' Legal Times, May 29, 1989, at 10. 
awareness of the presence of significant division that, if taken seriously, makes impossible any facile assumption of shared identities and perceptions.

The question asked of Justice Brennan presumably grew out of the same soil as did a letter from a Minneapolis citizen who saw in Pierce Butler's nomination by President Harding not an occasion for pride in the success of a fellow Minnesotan but rather the specter of "tighten[ing] the papal noose around the neck of America almost to the strangulation point." 65 To what extent is a Catholic bound to follow the strictures of a foreign potentate housed in Rome? Anti-Catholics, of course, have always found it far too easy to assume of Catholics that they are indeed bound to follow the pronouncements of the Pope on all matters of faith and morality. The image is presumably that of the automaton, who has ceded his or her capacity for judgment to some external agent. This is obviously grotesquely simple-minded. Anyone even dimly aware of the history of the Church knows of the heated arguments that indeed occurred, and are occurring, within it over matters of faith and morals.

Still, it is scarcely anti-Catholic to note the institutionalized nature of the Roman Catholic Church and, more particularly, the claims that have on occasion been made in behalf of its magisterium. Indeed, even as I was writing the most recent draft of this Article, the New York Times headlined that "Bishops Warn Politicians on Abortion," going on to describe a resolution passed at the annual National Conference of Catholic Bishops stating that "no Catholic can responsibly take a 'pro-choice' stand when the 'choice' in question" involves abortion. Some individual bishops apparently are suggesting that the Church might need "to look at" the possibility of excommunicating or otherwise sanctioning Catholic public officials who reject the Church's position. ${ }^{66}$

65. D. DANELSKI, supra note 29 , at 92 . There is also a similarity to the views enunciated by New York's Governor Mario Cuomo in an unusually thoughtful speech, "Religious Belief and Public Morality: A Catholic Governor's Perspective," at Notre Dame on September 13, 1984, in part given as a direct response to the criticisms he had received from officials in the Catholic hierarchy for his position on abortion. In that speech, Governor Cuomo accepted the premise:

[T]hat I have a salvific mission as a Catholic. Does this mean I am in conscience required to do everything $I$ can as Governor to translate all my religious values into the laws and regulations of the State of New York or the United States? Or be branded as a hypocrite if I don't?

T. Fort, LAW AND Religion 108 (1987) (quoting M. Cuomo, Religious Belief and Public Morality: A Catholic Governor's Perspective 6 (Sep. 13, 1984) (unpublished manuscript)). As one might expect, the answer to both of these questions is no. Cuomo emphasized that:

Our public morality, then-the moral standards we maintain for everyone, not just the ones we insist on in our private lives-depends on a consensus view of right and wrong. The values derived from religious belief will not-and should not-be accepted as part of the public morality unless they are shared by the pluralistic community at large, by consensus.

Id. at 107.

66. Steinfels, Bishops Warn Politicians on Abortion, N.Y. Times, Nov. 8, 1989, at A18, col. 1. See Goldman, Legislator Barred From Catholic Rite, N.Y. Times, Nov. 17, 1989, at A18, 
One way that we might understand (though I should immediately emphasize, not necessarily justify) the question directed at Justice Brennan is by placing

col. 1. The article describes the order by San Diego Bishop Leo T. Maher that California State Assemblywoman Lucy Killea refrain from receiving communion so long as she continues to support abortion rights as part of her campaign in a special election for the California Senate. In a letter to Killea, Bishop Maher stated that "by your media advertisements advocating the 'pro-choice- abortion position in the public forum, you are placing yourself in complete contradiction to the moral teachings of the Catholic Church." Id. at col. 2. He cited Canon 915 of the Code of Canon Law, giving him the right to deny communion to those who "obstinately persist in manifest grave sin." Jd. at col. 3. See also Steinfels, Question for Catholics, N.Y. Times, Nov. 20, 1989, at A16, col. 2 (analyzing Bishop Maher's action). Steinfels points out that "[b]ishops . . . have wide latitude to act in their own dioceses, which is often forgotten by many, including Catholics, who view the Catholic Church as a tightly organized body that speaks with a single voice." Id.

The New York Times commented on the subject further with an editorial "lament[ing]" Bishop Maher's action, even as the editorial stated that "[o]utsiders have no business challenging [his] religious authority to take such action." The Bishop and the Truce of Tolerance, N.Y. Times, Nov. $26,1989, \S 4$, at 12, col. 1. But the editorial writer, referring to Kennedy's "memorable pledge" at Houston that "I do not speak for the church and the church does not speak for me," strongly suggested that Bishop Maher's action threatens the "truce of tolerance by which Americans maintain civility and enlarge religious liberty." Id. According to the editorial, should other bishops join Maher:

[M]any non-Catholic Americans may once again be moved to withhold their trust from Catholic candidates who could no longer credibly promise to follow the Kennedy and Cuomo examples....

Above all, to force religious discipline on public of ficials risks destroying the fragile accommodations that Americans of all faiths and no faith have built with the bricks of the Constitution and the mortar of tolerance.

Id. at col. 2. This in turn was answered by a Times' reader, who described the paper's notion of "truce" as:

Timespeak to describe the situation in which a Roman Catholic may piously mouth his beliefs so long as he in no way acts on them ....

Bishop Maher is not forcing obedience to a religious political agenda, but simply reminding one of his flock that if she wants publicly to call herself a Catholic, she must abide by the church's teaching on the sanctity of human life. If she values her job above the tenets of her faith, she is free to make that choice ....

Spare us your crocodile tears over the impoverishment of American public life if "Catholic" politicians like the Kennedys and Cuomos lose the confidence of the electorate because of their so-called Catholicism. They are Catholic in name onlyprecisely the kind of Catholics you welcome or allow into the public arena. Real Catholics who live their faith need not venture out; their place is in the catacombs. Moreland, Letter to the Editor, N.Y. Times, Dec. 17, 1989, § E, at 20, col. 5.

The controversy continued upon the suggestion, by Bishop Austin Vaughan, that Governor Cuomo's soul might be endangered by his unwillingness to renounce Roe $v$. Wade. See supra note 24. Upon the seeming endorsement of this view by John Cardinal O'Connor of New York, Professor Arthur Schlesinger immediately wrote an op-ed piece in the New York Times arguing that "Bishop Vaughan and Cardinal O'Connor are in danger of vindicating those who have been saying that Catholics in politics must obey the ukases of Rome. The prelates seem to imply that Al Smith and John Kennedy were wrong in contending that Catholics in politics are as free as communicants of other faiths." Schlesinger, supra note 24. I strongly suspect that this debate continues even as this Article is being published.

In terms of the central focus of this Article, judicial nominations, one might want to distinguish 
it within the American concern, going back to 1795 , that its citizens-of at least the naturalized variety-publicly renounce commitments that are viewed as competing with the loyalties to the United States and to the Constitution that are at the heart of what limited national political identity we share. Thus to this day the United States requires of anyone who would become a naturalized member of the American polity not only an affirmative promise of fidelity to the Constitution but also a declaration that one is willing to "renounce and abjure absolutely and entirely all allegiance and fidelity to any foreign prince, potentate, state, or sovereignty of whom or which the petitioner was before a subject or citizen." ${ }_{67}$ I suspect that anti-Catholics in effect view the Pope as the "potentate" of a sovereign community, so that the question directed at Brennan is the equivalent of a demand for explicit renunciation and abjuration of what anti-Catholics perceive as a possibly competing loyalty. ${ }^{68}$ Of course, what is bothersome about this suggestion is precisely the application of what have become entirely secular categories to a body that envisions itself, after all, as the instantiation of Jesus Christ and the God whose son he is claimed to have been. But this is simply to repeat once again the essential problem that underlies this Article.

\section{Moral Judgement and Natural Law}

I want to suggest, moreover, that this emphasis on the role of the institutionalized Church as authoritative articulator of moral and theological truths may deflect us from recognizing the centrality of an even more fundamental issue, which is the role of moral judgment as an aspect of law. I don't want to suggest that the issue of institutional authority is unimportant. It is, for example, surely behind the current controversy over the status of Father

\footnotetext{
legislators from judges in terms of the far greater "free will" of the former relative to the "constrained" agency role of the latter as simple enforcers of legal command. A Supreme Court Justice supporting Roe can claim that he or she is simply fulfilling the command of the Constitution rather than engaging in any kind of discretionary choice about what counts as a preferable public policy. Two questions immediately arise, however: first, to what extent does this distinction between discretion and agency survive legal realism, especially in an area like abortion and so-called privacy rights? Second, even if one accepts the distinction, at what point must a moral judge at least recuse him or herself from decisions involving the enforcement of unjust law, not to mention the possible duty to resign entirely from the bench? For discussions of this point, see R. Cover, JUSTice ACcused (1975).

67. S. Levinson, supra note 4, at 103 (quoting the oath required by the Immigration and Nationality Act). Thus Justice Taney's biographer Carl Swisher notes that his nomination "was widely criticized on the ground that he was a Catholic, and therefore subservient to a 'foreign potentate."' C. SwISHER, ROGER B. TANEY 37 (1935), quoted in Perry, supra note 30, at 60.

68. Or consider the campaign for governor of Pennsylvania waged in 1857 by Republican candidate David Wilmot, who appealed to the nativist members of the American Party by emphasizing to naturalized citizens that they must acknowledge "no earthly power superior to the Constitution and the sovereignty of the American people" and then denouncing the presence in American politics of a "priestly order . . . acknowledging as their head a foreign potentate." Wilmot's campaign is discussed in Kenneth Stampp's forthcoming Eighteen Fifty-Seven (1990) (typed manuscript on file with the DePaul Law Review).
} 
Curran as a Catholic theologian, not to mention the criticism sometimes visited by Church officials upon Catholic politicians for their apparent deviation from Church positions in regard to abortion. But the question of institutional authority, however important, is joined to an even more substantial issue: can human beings discern-and feel bound by-transcendent moral norms?

Professor Greenawalt presents as "the traditional Roman Catholic perspective" a "belief in natural law" joined "with a vitally important role for authoritative statements of the church hierarchy." 69 From my perspective outside of the Church, I share what I take to be Professor Greenawalt's view that one of the defining tenets of the Roman Catholic community is the existence of moral claims upon us, the content of which can be known through the disciplined application of human reason. ${ }^{70}$ Thus arises the traditional Catholic emphasis on natural law and natural justice and the pro-

69. K. Greenawalt, Religious Convictions, supra note 41 , at 41 . See also the study of John Courtney Murray by Professor Luckey, supra note 37, who emphasizes the grounding of Murray's thought in natural law theory. Thus Murray, who emphasized the "relative autonomy" of the political order, nevertheless wrote that "[t]he limits of his [the ruler's] direct power are set by natural law." Id. at 9, quoting Murray, Governmental Repression of Heresy, in Proceedinos of the Catholic Theological Soclety of Ameruca 56 (1948). For Murray, the possibilities inherent in free government "can be realized only when the people as a whole are inwardly governed by the recognized imperatives of the universal moral law." Luckey, supra note 37, at 11, quoting J. Murray, We Hold These Truths: Catholic Reflections on the AMERICAN Proposition 24 (1960) (emphasis added). Luckey describes Murray as offering a notion of the United States Constitution that viewed it as having two aspects. "Firstly, it is a charter of freedom, recognizing human dignity and the right to choose what one ought. Secondly, it is a plan for political order, a plan based on these recognized principles of a universal moral law." Luckey, supra note 37, at 11.

Notre Dame Professor Richard P. McBrien offered an analysis of Murray in his own presentation at the Casassa Conference where I presented the initial version of the present Article. He cited Murray as rather sharply distinguishing between the realms of the moral law, which, in Murray's words, "governs the entire order of human conduct, personal and social; it extends even to motivations and interior acts." McBrien, Religion and Politics in America: A Catholic Reflection 19 (Mar. 9-10, 1989) (unpublished manuscript). On the other hand, the civil law "looks only to the public order of human society; it touches only external acts, and regards only values that are formally social." Id. For McBrien, the implication is that "the scope of civil law is limited and its moral aspirations are minimal. To have made the moral argument against abortion, therefore, is not necessarily to have made the legal argument as well." Id. at 20 (emphasis omitted).

70. I should note that the analysis of the binding nature of natural law in Catholic thought is considerably more complex than suggested in the text. Thus, Professor Frederick J. Crosson argues that for Aquinas, the duty to adhere to natural law did not come from simple rational cognition of its teachings, but rather from the fact that it is commanded by God "that good is to be done." Otherwise, the natural law is merely "a rule or standard by which human actions were to be measured," though not necessarily, to use a quintessential American term, invalidated. Crosson, supra note 13, at 87-88. Father McBrien agrees. See McBrien, supra note 69, at 19. He quotes Aquinas's comment, in Summa Theologica, II-I, quest. 96, art. 2, as saying that the civil law "does not lay upon the multitude of imperfect people the burdens of those who are already virtuous, namely, that they should abstain from all evil. Otherwise these imperfect ones, being unable to bear such precepts, would break out into yet greater evils." Id. 
pensity to judge the commands of positive law against the purported claims of natural law. And, as Professor Deak suggested, one consequence of such judgment may be to deligitimize, or invalidate, the authority of positive law. It is probably an overstatement to assert that Catholic doctrine holds that "an unjust law is not law at all." Although St. Augustine did in fact state that "a law that was unjust wouldn't seem to be the law," John Finnis argues that Thomas Aquinas presents a much more nuanced analysis. Aquinas's analysis allows the possibility of recognizing as valid-even though clearly not the "best" law-a legal command that violates the norms of natural law. Indeed, Finnis states that "[ $t]$ he tradition goes so far as to say that there may be an obligation to conform to some . . . unjust laws in order to uphold respect for the legal system as a whole." 72 In any event, it seems clear that immersion in traditional Catholic teachings about natural law at the very least would lead to a sensitivity about the justice of the alleged commands of the positive law. These are two different claims, of course. The first is epistemological, that it is possible to know what morality demands of us. The second is jurisprudential, that nothing should be accorded the dignity of being regarded as binding law if it manifests injustice. Both are obviously questions of the highest importance.

\section{The Law, Morality, and Catholic Justices}

At this point arises the central question of this discussion: Is it legitimate to be especially concerned about the views held regarding these epistemological and jurisprudential issues by someone who comes out of the Roman Catholic community? One might be more likely to ask Roman Catholic nominees such questions than, say, Lutherans, because the Catholic Church has historically insisted on the reality of natural law in a way that the Lutheran community has not.

The Constitution clearly prohibits religious tests for office. This means, presumably, that it would be illegitimate to make dispositive a nominee's belief-or lack thereof-in God, since a conscientious senator should be unable to take into account any given answer to that question. That being said, should we interpret the no test oath clause as equally prohibiting any inquiries motivated by the interlocutor's interest in the nominee's adherence

71. See J. Finnts, Natural Law and Natural Right 363 (1980) (section on "Lex injusta non est lex"').

72. Id. at 365. See Questions 90-96, First Part of the Second Part of the Summa Theologicam, in The Political Ideas of St. Thomas Aquinas (D. Bigongiari ed. 1953) (unjust laws "do not bind in conscience, except perhaps to avoid scandal or disturbance"). As noted by Professor Wright, the quoted passage puts to lie any easy notion that adherents to Thomistic natural law are "counseled to ... disobey [unjust] law, whatever the cost in disruption and scandal." Wright, Legal Obligation and the Natural Law, 23 GA. L. REv. 997, 1009 (1989). However, this basically instrumental defense for obeying what one believes to be an unjust law may not satisfy the state, which is looking for the kind of enthusiastic commitment that stills any embarrassing questions about the possibility and implications of unjust laws. 
to claims associated with the particular church or sect to which he or she is known to belong, especially those claims that have undoubted relevance to the conceptualization of one's role as an actor within the world? Consider, for example, Senator Howell Heflin's comment, in his opening statement during the Bork hearings, that " $[t]$ here are those who charge that Judge Bork is an agnostic or a non-believer. These critics contend that such beliefs will affect the opinions of the courts and hence, our churches, our synagogues and, ultimately, our lives." 73 Senator Heflin made this comment by way ostensibly of "remind[ing his] colleagues" about the no test oath provision of article VI and emphasizing that "it should be observed in pursuing any inquiry, whether it be legitimate or not, as to one's personal religious feelings," 74 though the context makes one doubt how genuine the Senator was in his protestations. The doubts are multiplied when one discovers that the Senator justified his ultimate vote against confirmation in part on religious grounds, telling his constituents, for example, that "I was . . . disturbed by his refusal to discuss his belief in God or the lack thereof." 75

Ethan Bronner, in his book on the Bork nomination, describes Heflin's opening statement as "inexcusable" and his return to the issue of Bork's religious beliefs as "shameless[]." 6 In an earlier draft of this Article, I described the statement as outrageous, given the inability of a constitutionally conscientious senator to base her vote on the religious beliefs of a nominee. I confess, with genuine trepidation, that I now think that the question might be more complicated, even if I remain willing to condemn Senator Heflin in the specific instance for his Nixonian hypocrisy in raising the issue by way of insisting that it should be excluded from the discussion.

The evaluation of Senator Heflin's remarks may be different if he had forthrightly stated the view that the presence or absence of "belief in God" might be relevant to one's fitness for public office. One might wish to deny this tout court by asserting a lack of empirical evidence that suggests that the gross attribute of "believer" or "nonbeliever" predicts anything interesting about the likely behavior of a person, but this assertion itself might be highly controversial. ${ }^{77}$ The traditional rationale given for disqualification of atheists is their presumed propensity to violate their oaths, given their lack of fear of a hereafter in which punishment would be visited upon sinners, but I assume that no one, at least in academic circles, would defend such a proposition. More seriously, one might believe that an atheist, as distinguished from an agnostic, might be less accepting of certain kinds of free exercise claims insofar as atheism is a more militant, Enlightenment-based rejection

73. E. BRONNER, supra note 44 , at 294-95.

74. Id.

75. Id. at 295 .

76. Id. at 294.

77. Thus Professor Silver has informed me that there is a sizable body "of empirical literature point[ing] to tendencies toward behavioral differences between believers and secularists. Letter from Allen Silver to Sanford Levinson 2 (Dec. 10, 1989) (copy on file with author). 
of religious "superstition" than the more tolerantly skeptical agnosticism. But this rationale brings one perilously close to the exaction of a test oath that is barred by article VI. Still, agreement that one could not legitimately base a vote on the bare answer to the question, "are you an atheist," does not prove that one cannot ask it at all.

\section{Permissible Inquiries and the Danger of Prejudice}

The appropriate American constitutional referent to the issue of atheism might be the cases decided by the Supreme Court during the 1950's and 1960 's dealing with the validity of asking candidates for the bar if they had been members of the Communist Party. ${ }^{78}$ To put it mildly, I am ambivalent about crediting them with any validity at all inasmuch as they were part and parcel of one of the least attractive eras of American public life. Still, with all the wariness that their backgrounds should compel, we might nonetheless examine their logic for any help they provide on the issue under discussion. Concomitantly, if one decides that religious commitments are absolutely ruled out as a subject of senatorial questioning, then that should certainly call into doubt the cogency of the cases mentioned.

As I understand these cases, the Court, even while rejecting the proposition that Communist Party membership per se would be enough to warrant rejection of an applicant for membership in the bar, indicated that Committees on Character and Fitness could nonetheless inquire as to membership. The rationale was that affirmative information as to membership could serve as a reasonable basis for a more probing conversation about questions arguably relevant to one's fitness to practice law or otherwise inhabit public office. ${ }^{79}$ The cognate question then might be whether, in spite of the clear prohibition of making any religious affirmation dispositive as to one's fitness for office, the equivalent of a committee on character and fitness-for instance, the Senate Judiciary Committee engaging in its constitutional power to advise and consent to appointments to the federal judiciary-may properly even seek information about one's religious views as the basis of further conversation about their implications relative to public office.

One might, of course, concede the relevance of a given question, but, at the same instant, make a policy decision to prohibit its being asked on the grounds that whatever quantum of relevant information will be garnered will be distorted in its application by the likely prejudice of the information seeker. This, of course, is precisely the analysis we use in the law of evidence,

78. E.g., Schware v. Board of Bar Examiners, 353 U.S. 232 (1957); Konigsberg v. State Bar, 353 U.S. 252 (1957), aff'g lower court decision on remand to deny petitioner bar admission, 366 U.S. 36 (1961).

79. See Konigsberg, 353 U.S. at 273-74 (fact of past membership in communist party, by itself, is an insufficient basis for finding an applicant disloyal or of bad character). The court limited the use of these inquiries later, however, in holding that a state could not ask broad questions about all organizations to which an applicant has been a member. E.g., Baird v. State Bar, 401 U.S. 1, 6 (1971); In re Stolar, 401 U.S. 23, 30 (1971). 
where the justified assertion of a question's relevance is in fact not always sufficient to overcome an objection predicated on its prejudicial potential. ${ }^{80}$ Here, too, one might even be willing to concede that information about a nominee's religious stance would be relevant, but nonetheless prohibit inquiries about that stance either because of the likely unfairness for the particular nominee or, more generally, because of the adverse consequences for the general tone of American public life. Still, the general thrust of the evidentiary system involves the desirability of presenting truthful information about relevant matters, and the burden of persuasion is usually placed on the person seeking to limit the scope of inquiry. ${ }^{81}$

\section{The Relevance of Morality}

The analysis of the standards of evaluating a public official's personal identity necessarily involves moral issues. Returning to the specific interrogations of our three Catholic nominees, I think that they can be subsumed under (something like) the following general questions:

You belong to a religious community that claims of human beings that they are able to discern, through a mixture of revelation and reason and presumably the help of authoritative Church officials, the requirements of morality and justice. That is, the Church has set itself resolutely against the various doctrines that can loosely be brought together under the rubric "moral skepticism," which suggest that nothing can be known about moral duties or, what is functionally similar, that moral positions are hopelessly idiosyncratic. First, do you accept the Church's teaching that genuine knowledge exists (and is knowable) as to what is required of us if we wish to be moral beings? Second, if you accept these ontological and epistemological claims, do you feel bound to accept the Church's teachings, whether delivered through Papal encyclical or the more general magisterium, concerning the specific content of natural law? Finally, do you accept the proposition asserted by distinguished theorists associated with the Church, including St. Augustine and, according to some, Thomas Aquinas, that any command by a putative sovereign that requires violation of natural law is not itself to be described as "law"?

Justice Brennan responded to the question about institutional authority, and he reassured his audience that the Constitution, rather than the Pope, would be the source of guidance as to his duties as a judge. But this way of putting the question-and answer-eludes what is surely the central question, which is whether constitutional adjudication in any important respect includes reference to moral norms of the kind claimed by the Church to exist-in other words, transcendental truths ascertainable through right reason. Justice Scalia

80. The Federal Rules of Evidence provide that relevant evidence "may be excluded if its probative value is substantially outweighed by the danger of unfair prejudice." FED. R. EvID. 403.

81. See Fed. R. Evid. 301 (" $[\mathrm{A}]$ presumption imposes on the party against whom it is directed the burden of going forward with evidence to rebut or meet the presumption"). 
indeed addressed this question, albeit slightly obliquely, and I want to explore some of the ramifications of his answer.

Recall that Scalia described the judge in a democratic society as "be[ing] bound by the determinations of that democratic society." That obligation extends even to laws "that I might even think in the largest sense are immoral in the results they produce. In no way would I let that influence my determination of how they apply." I think it is worth closely analyzing Scalia's venture in political theory. At the very least, he is clearly and unequivocally rejecting what I have described as the classic Catholic analysis of law, for Scalia strips law of any necessary connection to morality. The Constitution may require or prohibit many things, but it cannot be said that the Constitution either requires justice or prohibits immorality. Justice Scalia instead accepts in toto the notion that the authority of the Constitution-indeed its very meaning-comes from the sovereignty of the people. To say that the voice of the people is the voice of God is no idle metaphor, for the very point is that the voice of the people can supplant the voice of God.

The question whether popular sovereignty is limited by normative constraints, of course, goes back to the very beginning of our constitutional debates. Against Justice Chase's argument in Calder v. Bull $\$ 2$ that "certain vital principles," even if not overtly expressed in the constitutional text, would justify "overrul[ing] an apparent and flagrant abuse of legislative power," Justice Iredell answered that the Court was without authority to pronounce a law "void, merely because it is, in their judgment, contrary to the principles of natural justice." by a Catholic judge to reassure his interlocutor that he will behave properly as a judge. Scalia offers such reassurance by embracing a kind of legal positivism associated in American thought particularly with Justice Holmes, with its relentless repudiation of natural justice in favor of the judge's duty to acquiesce to the commands of those with political power. Wherein lies the paradox? It comes from the fact that Holmes was strongly reacting against the claims of natural law identified with the Catholic Church. ${ }^{84}$ Yet it has now become a standard part of our public rituals that Catholic nominees for the Supreme Court demonstrate their adherence to Holmesian positivism and, in effect, renounce, albeit sub silentio, certain doctrines identified with their church. ${ }^{85}$

82. 3 U.S. (3 Dall.) 386 (1798).

83. S. Levinson, supra note 4 , at 35-36 (quoting Calder v. Bull, 3 U.S. (3 Dall.) 386, $387-$ 89 (1798)).

84. See Holmes, Natural Law in Collected Legal Essays 310 (1920).

85. Professor Robert George of Princeton has taken issue with this sentence:

As I understand him, Scalia does not deny that there are objective moral truths; nor does he deny that these truths are accessible to reason; nor does he deny the authority of the magisterium to teach these truths; nor does he deny that positive law (including constitutional law) can be evaluated by reference to these truths; nor does he deny that one must avoid complicity in the wrongdoing of others. He does, I think, deny 
Justice Scalia's response to Senator Mathias is especially dramatic insofar as it appears to be an unusually broad abnegation of the role of moral analysis in constitutional decisionmaking. Consider two possible versions of Justice Scalia's argument. The first would be something like this: although one should strive to interpret the Constitution in a way that maximizes the congruence between the demands of morality, there are occasions when this will simply be impossible. The only plausible meaning of the Constitution will be one that recognizes its requirement of immorality or prohibition of what justice might require. The easiest historical example within American constitutional history is clearly slavery. No less a personage than John

that moral truths determine the meaning of positive laws (including constitutional provision). Thus, in his view, there really can be immoral positive laws; the positive law really can stand in conflict with the natural law. In cases of such conflict, Scalia apparently believes that his duty as a judge is to determine the meaning of the positive law and to render judgment accordingly. Now, it is this belief about judicial duty, I think, that generates your critique. How can a judge who believes in natural law hold that he has a duty to render judgment in accord with positive law even when the positive law in question is unjust (or otherwise immoral)?

According to natural law theorists, judges are under the same obligations of truth telling that the rest of us are under. If the law is in conflict with the natural law, the judge may not lie about it. If his duty is to give judgment according to the positive law, then he must either (i) do so or (ii) recuse himself. If he can give judgment according to immoral positive law without rendering himself formally or unfairly material[ly] complicit in its immorality, and without giving scandal, then he may licitly do so (though he may also licitly recuse himself). If not, then he must recuse himself. (A great deal of traditional casuistry has to do with problems of formal and material complicity in wrongdoing.)

But doesn't natural law theory say that a judge's duty is to give judgment according to the natural law in cases of conflict between natural and positive law? No. In my opinion, the question of how much legislative authority a judge has to translate the natural law into positive law by nullifying positive law which he believes to be unjust is a question of positive law, not natural law. Different political systems reasonably differ (both in theory and practice) as to how much legislative authority they confer upon judges. ... If his views about judicial duty make him a "positivist," his positivism does not, I think, place him in conflict with his Church's teachings about natural law.

Letter from Robert George to Sanford Levinson (April 3, 1990) (copy on file with the DePaul Law Review).

If one assumes that Scalia's position, as reconstructed by Professor George, is a possible position within Catholic natural law theory, one might still wonder if an equally serious Catholic could read authoritative Church material as requiring a more privileged position for the teachings of natural law when they are in conflict with (at least some readings) of positive law. If the latter is the case, then we would still be faced with the question as to the legitimacy of senators inquiring into the view of Catholic theology held by Catholic nominees. In any event, I am extremely grateful to Professor George for taking the time to analyze the point so thoughtfully, particularly given his expertise on the intricacies of natural law theory. See, e.g, George, Recent Criticism of Natural Law Theory, 55 U. CHI. L. REv. 1371 (1988) (book review); George, Moral Particularism, Thomism, and Traditions, 42 Rev. OF Metaprysics 593 (1989). I also direct the reader's attentation to Kannar, The Constitutional Catechism of Antonin Scalia, 99 YALE L.J. 1927 (1990), especially pp. 1310-20, where Kannar discusses Scalia's relation to Catholic thought. 
Marshall expressed his belief that slavery is contrary to the law of nature, even as he proceeded to rule that the trade was nonetheless legitimated by the conventions of public international law. ${ }^{86}$ Similarly, Marshall's colleague Joseph Story both denounced slavery as "repugnant to the great principles of Christian duty, the dictates of natural religion, the obligations of good faith and morality, and the eternal maxims of social justice" ${ }^{87}$ nevertheless, and, in Prigg $v$. Pennsylvania, ${ }^{88}$ upheld the constitutionality of the tyrannical fugitive slave clause because the maintenance of the rights of slave owners was necessary in order to guarantee the preservation of the Union. ${ }^{89}$

Justice Scalia seems, however, to be making an even stronger argument than the one I have just described, which says "only" that morality does not necessarily trump immoral commands of the Constitution. But this way of putting it does not necessarily stand for the proposition that morality is irrelevant to legal analysis. Imagine, for example, that one is presented with a genuinely "hard case." One may not be sure whether or not the fugitive slave clause applies, for example, or whether a previous precedent extends to the new case. Is it proper in resolving such hard cases to take account of the moral costs or benefits of deciding one way or the other? Would it be legitimate, for example, for the judge to say, "I will enforce the immoral fugitive slave clause when I am convinced beyond doubt that it applies, but in the absence of such overwhelming evidence, I will hold that it doesn't apply, because all applications involve the subordination of morality to mere popular sovereignty." We often find judges construing statutes in a way that does not raise constitutional problems because of a judicial policy in favor of minimizing the occasions for judicial invalidation of legislative activity. Would it be improper for a judge to announce that he or she will construe statutes in a way that minimizes their moral problems? This, presumably, would be the jurisprudence proffered by a "Dworkinian" nominee to the Supreme Court, who accepts the proposition that the Constitution must be construed, if at all possible, to be as morally attractive as possible in terms of some extra-constitutional theory of morality. Would we accept this as proper at the same time we would deny confirmation to an overtly religious nominee who indicated that she would construe the Constitution to cohere, if at all possible, with what God (or right reason) commands to humankind? ${ }^{90}$

86. S. Levinson, supra note 4, at 67 (quoting The Antelope, 23 U.S. (10 Wheat.) 66, 120 (1825)).

87. Id. at 67 (quoting United States v. La Juene Eugenie, 26 F. Cas. 832 (C.C. Mass. 1822) (No. 15,551)).

88. 41 U.S. (16 Pet.) 536 (1842).

89. See S. Levinson, supra note 4, at 67 . These dilemmas served as the basis of Cover's Justice Accused, which examined the patent conflict between law and morality that was resolved by so many judges in the name of the law. See R. Cover, supra note 66.

90. Both nominees would presumably accept the proposition that such coherence might not always be possible, so that they would then either have to lie about what they believed the law 
Consider in this context Professor Greenawalt's suggestion that a judge, faced with a moral-legal issue where the standard resources of analysis present

to require or to resign, perhaps to take up arms against a sufficiently iniquitous state.

In this context, Professor Stephen Siegel has asked in conversation, if we, members of the elite legal academy, respond differently to someone claiming a secular basis, say the philosophy of John Rawls, for the morality that she wishes to inject into legal analysis than to someone who presents an unabashedly religious background for the morality he sees as linked to resolution of the legal problem? From other presentations of this paper, I know that there are some who object not to the law-morality linkage as such, but rather to the possible penetration of law by religion-founded morality. The most worked-out versions of such an argument are found in Audi, The Separation of Church and State and the Obligations of Citizenship, 18 PHI. \& PuB. Afr. 259 (1989), and Nagel, Moral Conflict and Political Legitimacy, 16 PHIL. \& PuB. Afr. 215 (1987).

If one prefers a secular David Richards, see Richards, supra note 41 , at 1189 , to a religious Kent Greenawalt, is this anything more than an expression of the Enlightenment-based animus within the intellectual community to religion as such? Though understandably respectful of Greenawalt's abilities, Richards leaves no doubt that for him public discourse-and, of course, the decisions of state officials - should be as removed from religious articulations as possible. "The requirement of Lockean legitimacy is that all political power (both that exercised by leaders and by citizens) be justifiable in terms of secular interests, and citizens (like their leaders) have the responsibility to limit their political claims to such interests." Id. at 1200 . In form, though, Richards professes respect for religious sensibilities, even as he wishes to limit their domain. For a more old-fashioned, though one suspects not completely atypical view, see Sherry, Outlaw Blues, 87 Mich. L. Rev. 1418, 1427 (1989) (reviewing M. Tushnet, Red, White, and Blue (1988)). "[S]uch things as divine revelation and biblical literalism are irrational superstitious nonsense" and should fall within "the liberal tradition of excluding nonrational modes of discourse." Id. One can wonder, of course, precisely how we decide what is "irrational superstitious nonsense" or a "nonrational mode[] of discourse," especially if one is even a partial devotee of "post-structuralism" or any of the other critiques of confident rationalism that are so much a part of the contemporary intellectual culture.

For an interesting meditation on this problem, see Carter, The Religiously Devout Judge, 64 Notre DAME L. REv. 932, 944 (1989) ("'O]nce a judge's moral understanding is permitted to play a role, the liberal argument cannot distinguish religiously based knowledge from other moral knowledge, or at least, cannot do so without arguments that require a bit too much cognitive dissonance."). Professor Greenawalt ultimately distinguishes between the development of political views based at least in part on religious foundations and their articulation in the overt terms of one's religious convictions. Thus he writes that "I believe argument for political positions in the wider polity is more like legal argument than a candid account of all one finds relevant. One makes arguments likely to persuade and reassure the audience, and one makes arguments in terms that affirm more general political values. I do think people should acknowledge the place of religious convictions in their own positions, but I still believe it is counterproductive for debates on particular political issues to be formulated explicitly in terms of religious convictions." Greenawalt, Some Further Thoughts, supra note 41, at 1046 (emphasis in original). Professor Alan Hyde, responding to an earlier presentation of this Article, proffered the distinction between the "thinking about it" and the "writing it up" stage of adjudication: "[I]f the religious influence is only in the 'thinking about it' state, that influence is inevitable," though the judge, when "writing it up," should strive "to be consistent with any recognized theory of adjudication (positivism, Dworkin, original intent [etc.])," the assumption being, of course, than none of the "recognized" theories allow overt reference to religious norms. See Letter from Alan Hyde to Sanford Levinson (Dec. 12, 1989) (copy on file with author).

Quite different problems, of course, are raised by those who might want to reject all nominees bold enough to assert the relevance of rights not enumerated and to reject one variety or another 
"indeterminate" solutions, should feel authorized to look to the guidance that might be provided by her (necessarily particularistic) religious tradition to help provide an answer. Greenawalt offers the example of a judge interpreting an environmental statute and finding the statutory language void of direction. "Resolution of the issue seems finally to turn on how much respect is owed by humans to the natural world. ... I see no escape from the proposition that the judge ... may in such settings find it necessary to rely on his religiously informed answers to what is right."9l To be sure, Greenawalt cautions a judge to "be extremely wary of relying on religious convictions, especially when he recognizes that his premises or the positions they yield are not widely shared." Still, "when such judgments are genuinely unavoidable, the judge within the constraints of the judicial role, should be able to rely on religious premises" to at least a limited extent."?

Justice Scalia, I believe, can be read as rejecting either of these last two formulations, at least if one takes his colloquy with Senator Mathias seriously. Is this not the implication of his saying that "[i]n no way" would he let his perception of a statute or a constitutional clause as fundamentally immoral "influence my determination of how they apply" "?3 This is a far more radical thesis than the announcement that on occasion one would have to recognize the legitimacy of an immoral law, for he seems to be arguing that legal analysis does not include reference to moral norms. ${ }^{94}$ There would, of course, be nothing astonishing about such a thesis if one were a moral skeptic, fundamentally dubious about the existence of what Michael Moore has called "moral reality." "9s And I am in no way arguing that moral skeptics are wrong; in some of my other writings, I have defended positions identified with skepticism, though it would require another article to do justice to these debates.

of an allegedly pure textual or historical positivism. See, e.g., R. Bork, The Tempting of Ameruca: The Political Seduction of the LAW (1990). Much of the book is a vigorous (some would say dogmatic) attack on everyone-ranging from Samuel Chase and William Brennan to Oliver Wendell Holmes and John Marshall Harlan-who has ever suggested that judges might make any reference to norms not enumerated that could limit the power of political majorities as represented in legislatures. But Bork also describes as one of his purposes "to persuade Americans that no person should be nominated or confirmed who does not display both a grasp of and devotion to the philosophy of original understanding" Id. at 9.

91. K. Greenawalt, Religious Convictions, supra note 41, at 241.

92. Id.

93. See supra note $\mathbf{5 0}$ and accompanying text (transcript of confirmation hearing).

94. One might dispute this argument from the materials of conventional constitutional jurisprudence, for it certainly seems plausible to read both the ninth amendment and the privileges and immunities clause of the fourteenth amendment as directing the judge to take account of rights not enumerated that are retained by the people against governmental limitation. I have addressed the ninth amendment in Levinson, Constitutional Rhetoric and the Ninth Amendment, 64 Cho.[-]Kant L. Rev. 131 (1988).

95. Moore, Moral Reality, 1982 Wis. L. Rev. 1061; Moore, A Natural Law Theory of Interpretation, 58 S. CAL. L. REv. 278 (1985). 
There are good reasons to believe that Justice Scalia, whatever his statement to Senator Mathias, does not actually place a wall of separation between law and morality. Consider, for example, his use, in his eloquent concurring opinion in City of Richmond v. J.A. Croson Co., ${ }^{96}$ of the following passage from Alexander Bickel's The Morality of Consent: "The lesson of the great decisions of the Supreme Court and the lesson of contemporary history have been the same for at least a generation: discrimination on the basis of race is illegal, immoral, unconstitutional, inherently wrong, and destructive of democratic society." 97 The question raised by this litany is whether it is a merely contingent, happy fact that law, morality, and prudence (that is, what is instrumentally useful to maintaining a democratic society) are joined together in this instance or whether the immorality and destructiveness are part of what identifies racial discrimination as illegal. One might also be curious about one other joinder, that of the positive morality of the general social order with Scalia's own notions of morality. It is clearly possible, as demonstrated in Huck Finn among other places, for one's own morality to run counter to what the best folks in one's society deem fitting and proper. In any event, though he does not indicate the source of his moral convictions, there can be no doubt that Justice Scalia has them.

\section{CONCLUSION}

It should be clear that although I disagree with Justice Scalia on the merits of Croson-I do not see racial preferences as the particular kind of racial discrimination embraced in his and Bickel's analysis-I am not at all critical of his reference to morality. I do not see how the enterprise of constitutional analysis could be carried out if words like "just," "moral," "unjust," or "immoral" were excised from the judicial vocabulary. This is especially true because a systematic elimination of these words would tend as well to eliminate any reason for the reflective citizen to feel committed to the legal system, at least on any other than rawly instrumental prudential grounds, or to venerate the Constitution that ostensibly serves as the basis of the legal system. What is interesting is not whether law and morality are inevitably and inextricably connected in the practical doing of constitutional analysis, for surely the answer is yes, but how we come to terms with this fact on those occasions when it is most important to state the fundamental creed of our constitutional order, such as confirmation ceremonies. Generally speaking, I think we do a fairly terrible job of it. A process that leads men and women of undoubted intelligence and integrity to say things that they cannot possibly wish to have represented as their genuine reflections on complex and important matters scarcely provokes admiration.

96. 109 S. Ct. 706, 735 (1989).

97. Id. at 735 (Scalia, J., concurring) (quoting A. BiCKEL, ThE MoRauity of Consent 133 (1975)). 
I leave you, though, with one final question: if I have persuaded you that these events can be profitably described as representing the triumph of American civil religion, is this tale hopeful or cautionary? Or, in keeping with an earlier theme, for whom of us is it the one, for whom, the other? 
• 